\title{
Language wars: English education policy and practice in Bangladesh
}

\author{
Raqib Chowdhury and Ariful Haq Kabir
}

\author{
* Correspondence: \\ raqib.chowdhury@monash.edu \\ Monash University, Melbourne, \\ Australia
}

\begin{abstract}
Since its relatively recent independence in 1971, a total of seven national Education Commissions were formed, all of which placed various degrees of emphasis on the planning, pedagogy and learning of English in Bangladesh. Although the first Education Commission in 1974 aimed to 'decolonise' the education system and effectively exile English from the country, English has always remained a top priority in the school curriculum. Studies have linked this to residual colonial legacy inherited from the British education system.

In the backdrop of persistent nationalistic favouritism towards Bengali, English is still widely an area-specific language confined to academia, and English education is often still seen as a purely instrumentalist endeavour. However it is also important as a symbol of socio-intellectual elitism and prestige. Such mixed, often incongruous positions can be seen reflected in the way successive National Education Policies have interacted with Commissions, which some critics have pointed out were formed by various regimes to advance their political agenda and ideology rather than to further the country's pragmatic needs and achieve well-articulated and time-sensitive policy outcomes.

This article critically reviews the major trends of English education policy as enacted through four decades of reform and how English has played out in the education system in a developing country fast emerging as a rich ground of alternative educational research.

Through a brief chronology of education policy and commissions and drawing on the comparative shifts of emphasis on English through their recommendations over a period of four decades, the article situates the place of English within the pragmatics of a postcolonial mindset and the socio-cultural expectations of stakeholders, and deals with the complexities of transition from policy to practice. In particular it problematises the almost irreconcilable friction between English and Bengali forged through the nationalistic sentiment born in the Language Movement of 1952, an episode unique in the history of the world. Rather than looking into the politics of policy planning and implementation, it looks towards the possibility of an education system that can bring about a healthy juxtaposition between heritage and modernity.
\end{abstract}

Keywords: English language; English education; Education policy; Bangladesh

\section{Springer}

(c) 2014 Chowdhury and Kabir; licensee Springer. This is an Open Access article distributed under the terms of the Creative Commons Attribution License (http://creativecommons.org/licenses/by/4.0), which permits unrestricted use, distribution, and reproduction in any medium, provided the original work is properly credited. 


\section{Introduction}

Because of its undeniable role in human capital development in an increasingly globalised world, English is now widely accepted as having immense potential for individuals and societies. Indeed engagement with the global economy presupposes the acceptance of English as central to accessing the global market. Consequently, many countries in Asia, for example, the South East Asian countries, where English has been used as foreign language over decades, have adopted the teaching and learning of English in their education policies in response to the realities of a more globally connected world. Most countries in this region have long been concerned that incompetency in English language may result in keeping them lagged behind in taking economic advantages from the momentum generated by globalisation, of which English is arguably a major driving force. For example in 2001, the Chinese government introduced English as a compulsory subject in Class 3 in all elementary schools and instructed all public colleges and universities to use English as the main teaching language for technology and business related subjects (Nunan 2003). This resulted in massive changes through which China opened up to the English speaking world, in terms of trade and commerce, education and training, as well as through politics and development.

In the Indian subcontinent the colonial British rulers adopted the British education system in order to use education as a political tool aimed to prolong their domination (Altbach 2008). Despite being nearly 80 years since the colonisers left, in current day Bangladesh the use, teaching and learning of English language and education still mark a conspicuous continuity with the colonial period, while at the same time sustained friction between English and a nationalistic fervour in favour of Bengali can be felt to often surface in popular rhetoric. Such friction has created almost irreconcilable fractures in formulating unproblematic language policies in the country. This article deals with the major trends of the policies related to English education as enacted through four decades of reform and how the practice of English education has played out in the education system in Bangladesh. In doing so it critically juxtaposes the perceived statuses of English with Bengali in order to highlight and understand the ongoing clash between the two languages.

A large body of research has shown how education policy in Bangladesh has been embroiled in vested political interests from the very beginning of its emergence as an independent nation in 1971. Sadeque (2000, in Rahman 2010), for example reports the general lack of policy direction in Bangladesh's education sector, while Unterhalter et al. (2003) lament the futility of politics and the 'fragile dialogue' between policy makers and practitioners of English that have always characterised Bangladesh's education policy. Policy and practice have been 'fragmented and inconsistent' (Imam 2005), and to a large extent researchers have blamed this on the tendency of research and education policy development predominantly being the preserve of elite groups associated with the government (Unterhalter et al. 2003), and education policy and reform historically being largely dictated by international funding rather than expert opinion (Hamid 2009). In his comprehensive study on the relevance of humanities education in Bangladesh, Rahman (2010) has labelled the education system as characterised by 'internal and external inefficiency', devoid of 'productivity... and clear-cut objectives... and policy directions', 'stagnant', 'inadequate', 'out-dated', 'limited', and one that 'produces graduates with no productive skills' (p. 5). A newspaper report summarises the 
system as 'still sunk in theoretical or textbook education' (New Nation 2005, in Rahman 2010, p. 5). Aminuzzaman (n.d.) argues that the quality of education in Bangladesh has 'declined steadily, in some cases quite alarmingly, over the last two decades' and has been said to be 'characterised by a mismatch of the objectives and the curriculum' (Ali 2004, n. p.) - a discontinuity marked most conspicuously in English education. Rahman regrets that the country still confronts a dilemma on the language issue - should the medium of instruction be English or the mother tongue? Similarly Johanson (2000) bemoans the lack of a visionary plan and lack of policy in relation to English in Bangladesh. Indeed the acknowledgement of such deteriorating quality in education comes from within policy makers themselves - the 2003 National Education Committee (NEC) itself lamented the conspicuous lack of a language policy for Bangladesh.

While the education sector has seen successive expansion initiatives, such expansion has predominantly been 'linear' and quantitative, rather than 'vertical' or qualitative (Rahman 2010, p. 75). Although successive education commissions formed under various regimes dealt with these issues, little has been achieved due to ruling politicians' motivations in furthering their political agenda and ideology with little regard for the country's needs, rendering all attempts futile (Mazumder 2009; Roy 1998 in Rahman 2010). In particular the volatile political situation of post-independence Bangladesh the political turmoil of the mid-1970s, followed by the military coup of 1981 and a number of years of political repression, martial law, suppression of democracy, political volatility and stagnancy, have marked frustrating disjuncture in any attempt to produce a coherent, consistent and time-sensitive English language policy.

In the context of the relatively new nation of Bangladesh, these national education policies have been founded on a long chronology of slow development that can be traced back to the 200 year span of the British colonial period. The current 2010 Education Policy is the embodiment of trial and error of no less than five committees and commissions since Bangladesh's independence just over four decades ago. Despite differences in policy directions and emphases, what has consistently been at the forefront of these policy recommendations is an emphasis on reinforcing the emotive rhetoric (Unterhalter et al. 2003) of national identity forged in the Liberation War of 1971, which is seen as the nurturing ground of socio-economic development of the nation. Such strong sentimental ties naturally link closely to the powerful unifying factor of the nation's linguistic identity which constitutes the main concern of this paper. From 1998 to the present Bangladesh has seen a more or less steady economic growth which has nurtured the overall quality of education (Unterhalter et al. 2003) and consistent efforts in modernising the curriculum. With government policies finally acknowledging the need for qualitative improvement rather than quantitative expansion, there is glimmer of hope and certainty.

The next section situates the place of English within the current educational scenario of Bangladesh. It then presents a brief chronology of education policy and commissions. The final part of the article looks into the comparative shifts of emphasis on English through these policies and commission recommendations over a period of four decades. The article then indicates implications of the review in terms of its relevance to the current global context and concludes with a discussion on the implications of findings as well as suggestions in favour of the possibility of an education system that can bring about a healthy juxtaposition between heritage and modernity. 


\section{The study}

This critical review is based on a qualitative analysis of a range of policy documents (1971 - present) formulated by the different governments in the education sector at the state level in Bangladesh. The policy documents included a number of national education policies as well as commission reports, including the Bangladesh Education Commission Report - 1974, the English Teaching Taskforce Commission - 1976, the Bangladesh National Education Commission Report - 1988, the National Curriculum Committee 1991, the National Education Policy - 2000, the Bari Commission Report - 2002, the Miah Commission Report - 2004, and the National Education Policy - 2010. Policy documents can be treated as primary resources (Prior 2011) to explore the historical development of English education and how English has played out in the education system in Bangladesh. Instead of attempting to understand positivist 'what' questions, we have asked constructivist 'why' questions (Darlaston-Jones 2007) to unearth underlying ideologies and power relations embedded in the policies and reports. This approach allowed us to go beyond the physical entity of the documents to gain insights into the surrounding sociocultural and political contexts surrounding the production of these policy documents.

\section{Situating English and English education in Bangladesh}

The relative importance of a local language and English are not static, or, in themselves, good or bad. Nor can it be argued that promotion of the local language at the cost of English or vice-versa necessarily compromises either language. One's cultural and/or national identity is inevitably language dependent. This however becomes problematic when we consider that in the popular rhetoric of Bangladesh's national identity and learning, English has been historically positioned as antagonistic rather than complementary. Critics have pointed out that this can be seen as residual colonial mentality that continues to plague to implementation of education policies that favour the promotion of English across the nation's educational system. The ongoing friction between Bengali and English, both in policy and practice, and in the quintessential cultural temperament in the nation has left deep scars in the formation of an acceptable language policy to date.

Indeed the 2003 National Education Commission (NEC) pointed out that the indecision about a clear-cut language policy has brought the higher education sector to 'the verge of a disaster' (Rahman 2010, p. 93), with higher education students generally remaining poor in both Bengali and English. The Commission recommended the government to take measures in urgently formulating a National Language Policy to overcome the current confusion surrounding the issue of language, especially at the higher education level. In particular, to ensure that promotion of English did not compromise with Bengali, the government attempted to balance English and Bengali in national policies (Hamid 2009), as will be discussed in the next section.

Currently English is taught as a compulsory subject from Classes 1 to 12 in the national curriculum. With over 17 million children learning English, Bangladesh boasts one of the largest primary second language (L2) English populations in the world (Hamid \& Honan 2012, p. 141). Hamid and Honan (2012) point out that considering monolingual Bangladesh's per capita income (US\$540) [currently US\$1190, according to BBS, 2014] and Human Development Index (HDI) ranking $\left(146^{\text {th }}\right.$ out of 189 
countries), the state commitment to English seems to be 'ambitious and astounding', however at the same time, it is also very 'reasonable' and 'entirely appropriate' when we consider the discourses that link the English language with social and economic development in today's globalised world. In Bangladesh English is used as an international link language and unlike in neighbouring India, it is hardly a tool for interpersonal communication. Despite this, English has firmly established itself as an essential part of the country's socio-cultural and economic life due to its extensive use for specific purposes in education and research, commerce and international communication, as noted by a host of researchers (see Roshid 2014; Chowdhury \& Farooqui 2011; Rahman 2010; Chowdhury \& Le Ha 2008; Chowdhury 2003; Banu \& Sussex 2001).

Although English has been taught compulsorily in schools from primary to secondary level, students' performance in English is generally still found to be very poor (Chowdhury \& Kamal 2014). Imam (2005), for example reports that the average English language skill level of a university student is equivalent to the Class 7 level. In response to this problem, the government introduced Communicative English Teaching (CLT) in Class 6 in 1996, which has been extended up to Class 12 on an incremental basis since then (Podder 2013; Mazumder 2013). To supplement the government's efforts, various externally funded projects and programs have also been implemented - for example, the English Language Teaching Improvement Project (ELTIP- 1997-2001) funded by Department of International Development (DFID, UK), the Female Secondary School Assistance Project (FSSAP 2002-2008, Phases I \& II) funded by World Bank, the Secondary Education Sector Improvement Project (SESIP-1999-2006) funded by Asian Development Bank (ADB), and the Teaching Quality Improvement Project in Secondary Education (TQI-SEP 2006-2016, Phases I \& II) funded by ADB and Canadian International and Development Agency (CIDA), in order to train secondary school teachers based on CLT. Some programs have also been implemented by non-government organisations such as the Bangladesh Rural Advancement Committee (BRAC) with a view to further developing English education (Podder 2013).

Of note among these initiatives, in 2008 a nine year project, English in Action (EIA 2008-2017) was designed by the government with assistance from the Department of International Development (DFID, UK). Aiming to equip 30 million people with English language skills to enable them to engage in economic activities more effectively, the British Broadcasting Corporation (BBC World), Open University, UK and Open Learning Systems Educational Trust, South Africa have been working together in this project which emphasised the achievement of economic growth by providing English language as a tool for better access to the economy. The target group of this project is both the current and future workforce of Bangladesh, irrespective of their demographic and geographical locations, particularly school age children at the primary level. The project consists of three phases and together they include TV and radio programs to highlight the importance of learning English, introducing effective methodology of English language teachers through training, and developing institutional capacity to deliver future programs and courses. It is expected that an English language policy for the government of Bangladesh will also develop in this phase. In the third phase the project is expected to be institutionalised within the government and the formal education system so that a functional and feasible model of effective English language teaching can be ensured through media and outreach programs (Seargeant \& Erling 2011). 
Following the privatisation of primary and secondary education, the government approved the introduction of higher education in the private sector by promulgating the Private University Act in 1992 (Kabir 2010, 2012, 2013). Historically this marks a milestone in Bangladesh's English education at the tertiary level. All private universities have been using English as medium of instruction from the very beginning of their establishment (University Grants Commission 2011) from 1992 onwards. In the face of increasing competition, public universities have continued to optimise their practice of using English as medium of instruction with most departments introducing fundamental/ foundation courses on English language to develop English language skills to compete with local and global demands. The availability of lucrative credit-transfer arrangements with universities in English-speaking countries means that in private universities English is now considered even more as a prospective pathway to acquiring academic credentials of a more 'global' (and almost always 'Western') standard.

\section{Education commissions and committees: a brief chronology}

Both in the British period (1757-1947) and in the Pakistan period (1947-1971), the education system of the nation remained a contested space of uneven yet firm political interest. The now infamous Macaulay Minute of 1835 on Education conveniently positioned English literature as superior its oriental counterpart. Bureaucratically inspired and culturally patronising, the Minute allowed the colonisers to offer English education to create a class of obedient Indian administrators in the mould of British taste and attitudes. Once the British occupation ended in 1947, the then East Bengal (currently Bangladesh) became part of Pakistan, a neo-colonial state, in the name of the predominantly religious Two-Nation theory. Its first education conference was held in Karachi in 1947 which aimed to reassess the colonial education system and to realign it with Islamic religious ideology (Rahman et al. 2010). This allowed the education system of Pakistan to continue as a means to gaining political interest, albeit in a different guise by using embedded and espoused Islamic religious sentiment.

Once Bangladesh became independent in 1971, the state under various governments continued to reshape and recontextualise education system from a broader nationalistic perspective offering a range of conflicting rationales. A total of seven national education commissions and committees since then have been set up by the various political and military governments over the last 43 years. One of the significant aspects of these policy formulations is that of the continued political-ideological interests they have espoused. Once a new government came to power, a new education commission or committee was formed to formulate a new education policy. It can be said that all of these commissions and committees were inevitably influenced by the respective ruling party's political ideologies and used as a means to short-term political gain.

The first education commission of independent Bangladesh (Bangladesh Education Commission, BEC) was formed in 1972, led by eminent scientist of the country Dr Qudrat-i-Khuda (henceforth 'Khuda Commission'). The formation of this particular commission, immediately after the Liberation War, was strategically important - the changed political scenario with the euphoria and momentum of independence demanded that an independent commission would accomplish the long-felt noble but difficult job of eliminating the stagnancy of the country's education system. Despite 
support from a limited local infrastructure, this was a time of massive transition, which also saw the creation of the state's Constitution, which declared it the state's responsibility to provide education to all citizens:

It shall be a fundamental responsibility of the State to attain, through planned productive forces and a steady improvement in the material and cultural standard of living of the people, with a view to securing to its citizens the provision of the basic necessities of life, including food, clothing, shelter, education and medical care. (Government of Bangladesh 1972, Article 15, in Unterhalter et al. 2003).

This agenda is clearly reflected in the Preface to the BEC report, which states:

The Government has constituted this Commission in order to remove the lacking and lapses of the existing education system, to inspire the people for nation building through education and to lead the country in its effort to get equipped with work oriented modern knowledge and skills" (BEC 1974, in Rahman 2010, p. 89).

Historically a milestone in Bangladesh's history of education, the Khuda Commission published its report in May, 1974 with an aim to 'decolonise' the education system for the first time. It considered the four fundamental pillars of the Bangladesh Constitution nationalism, socialism, democracy and secularism - as the central principles of its education policy. The salient aim of the Khuda Commission was to flourish socialistic views and ideas within the newly-born country's young generation in order to establish a nondiscriminatory, egalitarian and just society. It measured education as the way to build Bengali nationalism and reformation of the society (Ministry of Education 1974). Based on this commission report, the then government also nationalised all primary schools. The University Grants Commission (UGC), the central regulatory and granting authority for all public sector universities in the country, praised this 1972 Commission saying it produced the 'most comprehensive review' by considering education as an 'agent of change' and placing it in a 'broad national perspective, suggesting continuous quality development' (Rahman 2010, p. 90).

Unfortunately the Khuda Commission recommendations never saw the day of light. Due to the political turmoil in 1975 that saw the assassination of the nation's founder Sheik Mujibur Rahman, the Commission report was shelved by the then military ruler, General Ziaur Rahman until 1979, marking a premature end to the BEC's recommendations. Instead, the state under General Zia initiated its own brand of enquiry to the system by forming an Advisory Council for National Education in order to review recommendations of the Khuda Commission report. However, the country went into political turmoil once again in 1982 when General Ershad took over state power. Until 1987, General Ershad followed the previous education systems formulated by his government and finally formed the Bangladesh National Education Commission (BNEC), headed by Professor Mofizuddin Ahmed in 1987, the 'Mofizuddin Commission', which submitted their report in 1988. Among other goals and objectives of this Commission, religious education for the first time was made compulsory in order to create 'religious sentiment' and human and moral values for the young generation. 
Democracy was restored in 1991 with Begum Khaleda Zia forming a newly elected government. Although no commission was formed during her first tenure (1991-1996), she constituted the National Curriculum Committee to realise reform agenda in the curriculum. In 1996, the Bangladesh Awami League came to power after 21 years under the leadership of Sheikh Hasina. Her government acknowledged the urgent need to implement the recommendations of the 1974 Khuda report and consequently a 56member committee headed by Professor Shamsul Haque was formed in 1997. This Committee was tasked with looking into how to implement the recommendations of the Khuda Commission report in the current situation. This Commission was closely followed by the formation of a Committee in 1998 to review the Commission's recommendations and was entrusted with the task of preparing a draft Education Policy for Bangladesh. The Committee finally published the National Education Policy of 2000 (NEP 2000) - the first such document since independence. In addition, this committee also prepared the National Plan of Action (NPA) on Education for All (EFA), in keeping with the recommendations of the first Education Commission of 1974.

In her second tenure (2001-2006), Begum Zia formed two education commissions, led by Professor M A Bari and Professor Moniruzzaman Miah in 2002 and 2003 respectively. The Bari Commission was designed to address the immediate implementable reforms across the overall education sector (Ministry of Education 2002). However, the immediate and inexplicable formation of another commission just after a year by the same government hindered the implementations of the Bari commission report. Although it is unclear as to why the second commission was formed, the Miah Commission adopted some of the issues recommended by the Bari Commission in their report. In particular it emphasised on technological and business education in order to 'transform' the population into sustainable human resources (Ministry of Education 2004). Consequently, the Miah Commission suggested improving quality education at all levels in relation to global demands and the coordination of different streams, particularly between primary and secondary education. The Commission also warned that the different teaching methods and curricula used in different streams of education had generated socioeconomic and intellectual discrepancies that ultimately created social injustice. They suggested introducing a unitrack secondary education policy to help reduce the gap between the different streams of education (Ministry of Education 2004).

In her second tenure as Prime Minister (2009-2013) Sheikh Hasina formed the Education Policy Formulation Committee in 2009, led by Professor Kabir Chowdhury, one of the original members of the Khuda Commission in 1972. This Committee was asked to integrate and incorporate recommendations of both the Khuda and Shamsul Haque Commissions into the policy. Through extensive feedback from people from different walks of life, this Committee developed a draft National Education Policy (NEP) in 2009, which was finalised and published in 2010. Interestingly, the Committee acknowledged the vested political interests of previous governments as responsible for hindering the implementation of recommendations thus far. The Committee also held the four pillars of the Bangladesh Constitution and the spirit of the Liberation War as the basis of formulating the National Education Policy (NEP 2010).

Aside from the aforementioned commissions and committees, successive governments also created two other commissions and committees which were mostly perfunctory and achieved nothing much of value: the University Enquiry Committee (UEC) of 1976-1978 
immediately followed the political changeover of 1975 and the aforementioned Bangladesh National Education Commission (BNEC) formed in 1988 by General Ershad who took over state power in a coup in 1982.

The current NEP 2010 has set up 30 aims and objectives in which the cultivation of human values is identified as the 'primary objective' of education in Bangladesh. It considers Bangladesh's national and international obligations, human rights and social norms and values and aims to make learners aware of freedom, human rights, justice and equity, qualities of good citizenry, national history and cultural tradition, moral and human values, and above all the sovereignty and integrity of the nation. This policy proposed to generate modern and scientific knowledge in transforming the current generation into skilled human resources. In doing so, it emphasised technical and vocational education in order to turn a large youth population into a vast pool of professional and skilled human resources (Ministry of Education 2010). Although in the preface to the NEP 2010 the Education Minister claimed that the NEP was not moulded on the ideology of any particular political party, the Minister hoped that the policy will help implement 'Vision 2021' and promised to establish a technologically advanced 'Digital Bangladesh'.

Also, in recognition of ethnic minorities, for the first time in the history of education in Bangladesh, the NEP 2010 proposed steps to facilitate learning in the mother language of the indigenous students at the primary level of education. It also suggested developing a uniform curricula and syllabus in specific subjects at the primary level in order to develop a non-discriminating education system and to facilitate easier integration of different streams along with major changes in the assessment system.

As can be seen from this chronology, the fragmented, staccato and discontinuous nature of policy direction in education in Bangladesh has failed to bring about sustained development of educational policies in the country with recommendations made largely remaining unimplemented, or whatever implemented being merely 'tokenistic' (Rahman 2010, p. 94) to serve perfunctory political and ideological agendas. In particular, the premature demise of the original BEC 1974 and the subsequent regimes' failures in articulating a number of well-defined policy directions failed to facilitate sustained qualitative changes in education in a period spanning four decades.

\section{English in policy: changing shifts of emphasis}

Historically, even during the Indian subcontinent's British rule of 1757-1947, English had never been an essential subject at the primary level. During the Pakistan period (1947-1971), it served as the 'link language' between the two linguistically diverse Pakistans. Even so, English was not a compulsory primary school subject and certainly not a medium of instruction. The Language Movement of 1952, in which the then East Pakistan (now Bangladesh) resisted West Pakistan's (now Pakistan) imposition of Urdu as the sole national language, marks a milestone in the history of Bangladesh and had triggered the proliberation movement which culminated in the Liberation War of 1971. It was the birth of Bangladesh that marked the end of the multilingual character of divided Pakistan and the adoption of a monolingual identity for the first time in its history. Due to the lingering political influence of the decisive 1952 Language Movement, today Bengali still plays a sentimental role in national identity formation and this has been reflected in the language war 
between Bengali and English at both the policy level and in everyday adoption of a language for communication.

In fact, until the NEP 2010, Bangladesh never had any specific and consistent English language policy, nor any straightforward and coherent strategy of using English language at various education levels. The following table (Table 1) shows a brief chronology of the changing shifts of emphasis on English and English education as enacted within the various aforementioned education policies and commissions reports since independence.

By no means linear and even, and marked by conspicuous disjuncture and discontinuities, the case of English, as can be seen, however gained momentum over time, so

Table 1 English and English education in policy: A chronological summary

\begin{tabular}{|c|c|}
\hline $\begin{array}{l}\text { Education policies and } \\
\text { commission reports }\end{array}$ & The position of English and English education \\
\hline \multirow{2}{*}{$\begin{array}{l}1974 \text { Bangladesh Education } \\
\text { Commission }\end{array}$} & English given priority as foreign language, to be taught from Class 6 \\
\hline & General emphasis on English language \\
\hline $\begin{array}{l}1976 \text { English Teaching Taskforce } \\
\text { Commission }\end{array}$ & $\begin{array}{l}\text { English to be taught either in Class } 3 \text { or Class } 6 \text {, subject to availability of } \\
\text { English teachers }\end{array}$ \\
\hline \multirow{2}{*}{$\begin{array}{l}1988 \text { Bangladesh National } \\
\text { Education Commission }\end{array}$} & Grade 3 suggested as recommended starting point for English education \\
\hline & Grade 6 suggested as uniform starting point for English education \\
\hline \multirow{2}{*}{$\begin{array}{l}1991 \text { National Curriculum } \\
\text { Committee }\end{array}$} & English education introduced in Class 3 \\
\hline & English introduced as compulsory subject in Class 1 (1992) \\
\hline \multirow[t]{5}{*}{2000 National Education Policy } & English set as medium of instruction for kindergartens \\
\hline & $\begin{array}{l}\text { Curriculum and all text material used in kindergarten translated into } \\
\text { English }\end{array}$ \\
\hline & $\begin{array}{l}\text { Introduction of English as extra subject from Class } 1 \text { and } 2 \text { and as } \\
\text { compulsory subject from Class } 3\end{array}$ \\
\hline & $\begin{array}{l}\text { Along with Bengali, English could be medium of instruction from the } \\
\text { secondary level (Class } 7 \text { ) }\end{array}$ \\
\hline & Emphasis on English as medium of instruction at the tertiary level \\
\hline \multirow{5}{*}{$\begin{array}{l}2003 \text { National Education } \\
\text { Commission }\end{array}$} & Reemphasis on English learning from the primary level \\
\hline & $\begin{array}{l}\text { One objective of primary education to acquaint learners to English } \\
\text { language skills as a foreign language }\end{array}$ \\
\hline & Emphasis on rebuilding overall English curriculum \\
\hline & $\begin{array}{l}\text { Emphasis on organising foreign training for trainers of PTI and NAPE and } \\
\text { local training for all secondary school teachers to improve English } \\
\text { education }\end{array}$ \\
\hline & $\begin{array}{l}\text { Emphasis on introducing a six-month English language course at the } \\
\text { tertiary level }\end{array}$ \\
\hline \multirow[t]{8}{*}{2010 National Education Policy } & English recognised as essential tool to building knowledge-based society \\
\hline & $\begin{array}{l}\text { Emphasis on English writing and speaking from the very beginning of } \\
\text { primary education }\end{array}$ \\
\hline & $\begin{array}{l}\text { English to be set as compulsory subject adopted in all streams from the } \\
\text { secondary level }\end{array}$ \\
\hline & $\begin{array}{l}\text { English as medium of instruction could be introduced from the } \\
\text { secondary level }\end{array}$ \\
\hline & $\begin{array}{l}\text { Emphasis on appointing adequate number of English teachers at } \\
\text { secondary level }\end{array}$ \\
\hline & English to be a compulsory subject in all colleges and universities \\
\hline & $\begin{array}{l}\text { English (along with Bengali) to be the mediums of instruction at the } \\
\text { tertiary level }\end{array}$ \\
\hline & Emphasis on the need to translate books written in English to Bengali \\
\hline
\end{tabular}


that its adoption became more robust and purposive especially in the last decade. Concurrently a rather toned down compromise between English and Bengali can be seen in more recent years.

Although the first Education Commission affirmed Bengali to be the only medium of instruction from primary to higher education level, it also acknowledged the importance of learning at least one foreign language as second language from Class 6. Broadly speaking, this recommendation was inherently in favour of English because of the country's inherited legacy from its British colonial history. The commission report had recommended:

It needs to be ensured that students from Class 6 to higher secondary level can study English as a second language so that they can gather knowledge from different books and journals written in English at the higher level education. At this stage it needs to give emphasis on language education rather than literature to learn English. (Ministry of Education 1974, p. 14)

The 1972 Constitution gave Bengali the status of the sole national language to be used in administration and the judiciary, and as medium of instruction in education, while English was to be taught only from Classes 6 to 12. To this end, higher education was to be delivered exclusively through Bengali. Sen (2008) regrets such postindependence policy decision to exile English from the country, a preference in favour of Bengali that would have long-term repercussions. Hamid et al. (2013) report how gradually over the next decade or so policy makers started realising the 'damage' (p. 150) done to English teaching and learning as a consequence of such nationalist policies. The sentimental rhetoric in favour of Bengali saw English as a 'great challenge' to national language and national identity, a 'displacer of national tradition' (Imam 2005, p. 481), and threatening a 'cultural recolonization', especially because of its dominance among the Bangladeshi elite. This sentimental undercurrent running in the opposite direction threw the momentum of the perceived importance of English into confusion throughout the next decade.

Although the 1972 BEC did acknowledge the instrumental role of English, it was not until 1976 when the English Teaching Task Force commissioned by the Ministry of Education first made explicit recommendations in favour of using English by proposing that, subject to availability of teachers, English be introduced either in Class 3 or Class 6. In 1976 the National Curriculum Committee made English a compulsory subject from Class 3. Based on the Bangladesh National Education Commission report 1988, the Ministry of Education decided Grade 6 to be the uniform starting point for English across all streams of education, however, it was also in favour of introducing English much earlier, in Grade 3 (Ministry of Education 1988).

Three years later in 1991 the National Curriculum Committee recommended introducing English in Class 3, although officially English was made a compulsory subject in Class 1 in 1992 in the wake of a major educational reform, although this was not implemented until 1997. Hamid et al. (2012, p. 141) report that such 'enhanced English access policy' was surprising, considering that this was not a recommendation of the Task Force or the National Curriculum Committee. In 1992 through the introduction of competency-based primary curriculum, for the first time English was made a compulsory subject from Class 
1 (Ahmed 2005). It was not until another eight years that English was introduced as a compulsory subject for all new undergraduate students at universities across the country (Hamid 2000, in Hamid and Honan 2012).

It is curious to note that in the nation's very first education policy, the NEC 2000, English had been considered as the medium of instruction for kindergartens. In this policy, kindergartens were identified as feeder schools for Ordinary $(\mathrm{O})$ and Advance (A) levels of education in English medium schools. The policy also suggested that kindergartens would use the same books and curriculum designed for the primary level by the government, but needed to translate them into English. For the first time, the NEP 2000 also suggested introducing English as an extra subject in Classes 1 and 2, with strong recommendation for the introduction of it as a compulsory subject from Class 3. It noted that Bengali and English would be used as mediums of instruction for Bangladeshi and foreign students respectively at the secondary level. In addition, NEP 2000 suggested that English could be 'useful' as a medium of instruction at the higher education level due to the scarcity of books and appropriate teaching materials in Bengali (Ministry of Education 2000).

Building on this momentum in favour of English, the 2003 National Education Commission emphasised on learning English from the primary level. It declared that one of the fundamental objectives of primary education was to acquaint students with the English language, and to achieve primary skills and use English as a useful foreign language. However the Commission was not in favour of using any particular book for the students in Classes 1 and 2; rather they recommended rebuilding the overall English curriculum. In order to improve English education, this Commission suggested organising overseas training for trainers in the Primary Teachers Institute (PTI) and the National Academy for Primary Education (NAPE), as well as local training programs for all secondary school teachers. The Commission found that there was no clear understanding of the objectives of 'communicative English' among secondary level teachers and therefore it proposed stressing on English grammar from Class 6. As for higher education, the Commission found that in the absence of a national language policy and the dilemma regarding which language to use in higher education, students remained weak in both Bengali and English. To this end, the Commission proposed to introduce a six-month English and Bengali language course for all undergraduate students to improve their language skills.

In the country's latest education policy, the National Education Policy 2010, English education has been given greater importance with a view to building a strong and progressive knowledge-based and information technology-oriented society. The policy recommended that appropriate steps needed to be adopted from the very beginning of primary education to enhance English writing and speaking skills which were to be continued at higher levels to allow students acquire usable skills. At the secondary level, in addition to English being a compulsory subject across all formal education, any school could choose to introduce English as a medium of instruction. In order to ensure better English education, English teachers were to be appointed in high schools, while in higher education, as well as being a medium of instruction (along with Bengali), English was to be considered as a compulsory subject in all colleges and universities. The Policy also emphasised the need to translate books written in English to Bengali to meet international standards. 


\section{Implications of findings}

Through a critical consideration of the chronology of English in the nation's successive policies this paper attempted to reproblematise the status of English as perceived by the government and education policy makers in Bangladesh. In doing so, persistent friction has been seen to exist between English and Bengali, especially given its historical status in relation to the country's independence and the populist fervour it commands. Based on the findings derived from policy document analysis and a critical review of the literature, the following steps could be considered by policy makers and educators in Bangladesh in order to bridge gaps between the two languages and consolidate a language policy which aligns with the principles of the nation's educational development.

The 200 year history of British colonial rule and its politically inspired regressive education policy left the country without any time-appropriate policy direction and misplaced emphasis on lesser issues. Within such elitist education system, English was the only medium of communication for administration, judicial work and media communication. English medium schools were created to produce generations of privileged albeit subordinated groups of native people as administrators and professionals in power. We have seen that residual colonial mentality still strives in postcolonial Bangladesh. Kachru (1998) reports how, even in 1995 an 'outspoken' senior officer of the British Council clarified their vested interests in maintaining the role of English, and of British ELT as a trade. Consequently, on the one hand, some policy makers in Bangladesh often imaged English as a tool of continuing colonial imperialism which led them to decolonise the education system by formulating the first Education Commission. On the other hand, some policy makers themselves consolidated such colonial mentality as to identify English as an exclusive education for a certain group of privileged and empowered people. Such counteracting approach by policy makers has denied English to be an 'institutionalized additional language' (Kachru 1998, p. 93) in Bangladesh as it is in India, Malaysia, Singapore and Sri Lanka. Therefore the current English curriculum can still be said to remain 'elitist', as Rahman (2010, p. 4) argues. Often students' incompetence in English has made them vulnerable to continue their further higher education. As Hamid et al. (2012) point out,

The reality of the context for most Bangladeshi students is that, although the ability to use English is socially desirable, students with poor English grades but enviable functional competence can be denied access to higher education in the public sector. (p. 153)

Consequently, English education policy needs to be freed from such contending mentalities originating from both nationalistic and elitist mentalities and treated as a truly global language rather than a language that dominated our socio-politics and educational system over a long period of history.

Second, the emergence of English as global language has brought about significant changes to the education policy and practice in education systems around the world. Many countries in Asia have adopted English as an official language or have recognised it as the priority foreign language to compete in the global market (Nunan, 2003). In line with this, the latest National Education Policy 2010 identified English education as 
the tool to create a knowledge-based society. However, lack of English communication skills continue to challenge Bangladesh's industrial workforce to compete in the global market. Roshid and Webb (2013) have pointed out that the gap between theoretical knowledge and the practical experiences of the workplace have kept away industrial workers from participating more fully in the fiercely competitive global job market. They argue that university graduates in Bangladesh are still not well trained in English to the extent that they could enhance graduate opportunities and invest in their performance in the industry. Therefore, given the importance of the English in both global and regional contexts, policy makers need to rethink how the English curriculum can be redesigned to address such existing gaps in tertiary education.

Third, but not last, the current government (currently serving its second consecutive term) came to power in 2009 by chanting the slogan of turning the country into 'Digital Bangladesh', with the promise of facilitating the smooth entry of future generations into the globally connected $21^{\text {st }}$ century. In order to transform the country into a truly 'Digital Bangladesh', English education could be one of the key vehicles considering that the global knowledge production system is almost singularly dominated by the English language. Consequently policy makers and educators need to develop a kind of English education mechanism in the nation's education system that can help the young generation to relate the global knowledge system in tune with the zeitgeist of the new Asian Century.

\section{Conclusion}

We have seen the complex capillaries of factors through which education priorities of successive governments have been determined in relation to English education in Bangladesh. We have characterised the relationship of policy makers and researchers as often being a 'fragile dialogue' (after Unterhalter et al. 2003) and have seen the intricacies surrounding the dialogical process of policy formulation, implementation, evaluation, reflection and critique. Rather than looking into the politics of policy planning and implementation, this paper has looked at the momentum of its cultural/linguistic and historical narratives, and through it, the possibility of an education system that can bring about a healthy juxtaposition between heritage and modernity.

Unterhalter et al. (2003) regret that most research and policy critique is not disseminated to education practitioners and administrators, while academics and researchers on most occasions have remained on the receiving end of 'strong political rhetoric' (p. 96), rendering any possibility of meaningful dialogue futile. However, a long-term retrospection of language policy, in terms of the nation's historical and cultural discourses, clearly shows signs of progression and more favourable conditions in which new spaces are gradually opening up. The development of policies and curriculum directives is a continuous process, and it builds on the legacy of past generations, hence the challenge for educational language policy is not just a matter of resolving the friction between national tradition and global influence, or indeed Bengali and English. Instead, it is more about how successive generations can sustain its own project in furthering education in response to the demands of the time blending traditional and modern practices within an increasingly global world. In line with Imam's (2005) argument, competence in English is not in itself sufficient if it is not sustained by local social-economic strength and strategically competent political leadership. 
Curricular reforms need to make it more job-oriented, localised and problem-oriented and at the same time aim to empower the masses intellectually as well as economically.

Regarding the friction between Bengali and English, there is renewed need to push for 'universal literacy' (see Imam, p. 482) in both languages, rather than compromising any one for the other. Imam also calls for the need for a space that allows the evolution of a distinctively 'Bangladeshi style' of English inflected by national characteristics. Phillipson's (2009) proposal for education policies to embrace 'multilingual aims and means' building on local resources and opening up spaces to allow a new 'attitude' Seidlhofer (2004) will enable the establishment of its national identity (p. 49) more firmly. These changes need to be responsive to the need for an educated manpower and the economic expediencies of society.

\section{Competing interests}

The authors declare that they have no competing interests.

\section{Authors' contributions}

RC developed the idea and designed the paper, whereas AHK analysed the secondary materials of the paper. Both contributed in reshaping the paper critically. Both authors read and approved the final manuscript.

Received: 3 March 2014 Accepted: 15 August 2014

Published online: 16 September 2014

\section{References}

Ahmed, Manzoor. 2005. Teaching English in the primary school: challenges and options. Bangladesh Education Journal 4(1): 17-23.

Ali, Mohammad Ashraf. 2004. Poor Standard of Education: Inefficiency Takes its Toll. http://archive.thedailystar.net/2004/ 01/16/d40116150190.htm. Accessed 10 December 2013.

Altbach, Philip G. 2008. Literary colonialism: books in the third world. In Indigenous Knowledge and Education: Sites of Struggle, Strength, and Survivance, ed. Malia Villegas, Sabina Rak Neugebauer, and Kerry R Venegas, 55-64. Cambridge: Harvard Educational Review.

Aminuzzaman, Salahuddin Mohammad. Quality Issues of Higher Education in Bangladesh. http://heglobal.international. gbtesting.net/media/4289/quality\%20issues\%20of\%20higher\%20education\%20in\%20bangladesh.pdf. Accessed 10 December 2013.

Banu, Rahela, and Roland Sussex. 2001. English in Bangladesh after independence: dynamics of policy and practice. In Who is Centric Now? The Present State of Post-Colonial Englishes, ed. Bruce Moore, 122-147. Melbourne: Oxford University Press.

Chowdhury, Raqib, and Munasir Kamal. 2014. Balancing conformity and empowerment: the challenges of critical needs analysis in an EAP course at Dhaka University. In English for Academic Purposes in Asia: Negotiating Appropriate Practices in a Global Context, ed. Indika Liyanage and Tony Walker, 79-92. Rotterdam: Sense Publishers.

Chowdhury, Raqib, and Sabrin Farooqui. 2011. Teacher training and teaching practice: the changing landscape of ELT in secondary education in Bangladesh. In English Language Education in South Asia: From Policy to Pedagogy, ed. L Farrell, UN Singh, and RA Giri, 147-159. Delhi: Cambridge University Press.

Chowdhury, Raqib. 2003. International TESOL training and EFL contexts: the cultural disillusionment factor. Australian Journal of Education 47(3): 283-302.

Chowdhury, Raqib, and Phan Le Ha. 2008. Towards locally sensitive and meaningful pedagogy in ELT: Bangladeshi perspectives. Asia Pacific Journal of Education 28(3): 305-316.

Darlaston-Jones, Dawn. 2007. Making connections: the relationship between epistemology and research methods. The Australian Community Psychologist 19(1): 19-26.

Hamid, Mohammad Obaidul. 2009. National planning of European languages in Bangladesh. Dhaka University Studies 66(1): 57-64.

Hamid, Mohammad Obaidul, and Eileen Honan. 2012. Communicative English in the primary classroom: implications for English-in-education policy and practice in Bangladesh. Language, Culture and Curriculum 25(2): 139-156. doi:10.1080/07908318.2012.678854.

Hamid, Mohammad Obaidul, Iffat Jahan, and Mohammad Monjurul Islam. 2013. Medium of instruction policies and language practices, ideologies and institutional divides: voices of teachers and students in a private university in Bangladesh. Current Issues in Language Planning 14(1): 144-163. doi: 10.1080/14664208.2013.771417.

Imam, Syeda Rumnaz. 2005. English as a global language and the question of nation-building education in Bangladesh. Comparative Education 41(4): 471-486. doi:10.1080/03050060500317588.

Johanson, Richard. 2000. Bangladesh higher education in Bangladesh education sector review. Dhaka: The University Press Limited \& The World Bank.

Kabir, Ariful Haq. 2010. Neoliberal policy in the higher education sector in Bangladesh: autonomy of public universities and the role of the state. Policy Futures in Education 8(6): 619-631. doi:10.2304/pfie.2010.8.6.619.

Kabir, Ariful Haq. 2012. Neoliberal hegemony and the ideological transformation of higher education sector in Bangladesh. Critical Literacy: Theories and Practices Journal 6(2): 2-15. 
Kabir, Ariful Haq. 2013. Neoliberalism, international financial institutions (IFIs), and a vision for higher education in Bangladesh. In Research and Educational Change in Bangladesh, ed. Janinka Greenwood, John Everatt, Ariful Haq Kabir, and Safayet Alam, 1-16. Dhaka: Dhaka University Press.

Kachru, Braj Bihari. 1998. English as an Asian language. Links and letters 5: 89-108.

Mazumder, Abu Talha. 2009. Thoughts on education commission. Dhaka: Daily Ittefaq.

Mazumder, Sanjoy. 2013. Bangladeshi secondary teacher educators' experiences and perceptions of the application of communicative language teaching (CLT). In Research and Educational Change in Bangladesh, ed. Janinka Greenwood, John Everatt, Ariful Haq Kabir, and Safayet Alam, 99-113. Dhaka: Dhaka University Press.

Ministry of Education. 1974. Bangladesh Shikkha Commission Report [Bangladesh Education Commission Report]. Dhaka: Ministry of Education.

Ministry of Education. 1988. Bangladesh Jatiyo Shikkha Commission Report [Bangladesh National Education Commission Report]. Dhaka: Ministry of Education.

Ministry of Education. 2000. Jatiyo shikkha nity [National Education Policy]. Dhaka: Ministry of Education.

Ministry of Education. 2002. Shikkha Biseshoggo Committee Protibedon [Education Expert Committee Report]. Dhaka: Ministry of Education.

Ministry of Education. 2004. Jatiyo Shikkha Commission Protibedon [National Education Commission Report]. Dhaka: Ministry of Education.

Ministry of Education. 2010. National Education Policy 2010. Dhaka: Ministry of Education.

Nunan, David. 2003. The impact of English as a global language on educational policies and practices in the Asia-Pacific Region. TESOL Quarterly 37(4): 589-613.

Phillipson, Robert. 2009. Linguistic Imperialism Continued. New York: Routledge.

Podder, Ranjit. 2013. English Aural-Oral skills assessment policy and practices in Bangladesh secondary education. In Research and Educational Change in Bangladesh, ed. Janinka Greenwood, John Everatt, Ariful Haq Kabir, and Safayet Alam, 53-67. Dhaka: Dhaka University Press.

Prior, Lindsay. 2011. Using documents in social research. In Qualitative Research: Issues of Theory, Method and Practice, ed. David Silverman, 93-110. Los Angeles, London, New Delhi, Singapore, \& Washington DC: Sage.

Rahman, Muhammad Mustafizur, Mohd Izham, Hamzah Mohd, T Subahan Meerah, and Mizan Rahman. 2010. Historical development of secondary education in Bangladesh: colonial period to $21^{\text {st }}$ century. International Education Studies 3(1): 114-125.

Rahman, Mijanur. 2010. Improving the Relevance of Humanities Higher Education in Bangladesh. Melbourne: Monash University. Unpublished PhD thesis, available at: http://arrow.monash.edu.au/hdl/1959.1/475306. Accessed 2 February 2014.

Roshid, Mohammad Moninoor. 2014. Pragmatic strategies of ELF speakers: a case study in international business communication. In Enacting English Across Borders: Critical Studies in the Asia Pacific, ed. Raqib Chowdhury and Roby Marlina, 45-71. Newcastle upon Tyne, UK: Cambridge Scholars Publishing.

Roshid, Mohammad Moninoor, and Susan Webb. 2013. From workplace learning to work integrated learning for English communication skills: professional development in an international business sector. In Research and Educational Change in Bangladesh, ed. Janinka Greenwood, John Everatt, Ariful Haq Kabir, and Safayet Alam, 115-133. Dhaka: Dhaka University Press.

Seargeant, Philip, and Elizabeth J Erling. 2011. The Discourse of 'English as a Language for International Development: Policy Assumptions and Practical Challenges. http://www.teachingenglish.org.uk/sites/teacheng/files/Z413\%20EDB\% 20Section12.pdf. Accessed 22 September 2013.

Seidlhofer, Barbara. 2004. Research perspectives in teaching English as a lingua franca. Annual Review of Applied Linguistics 24: 209-239.

Sen, Aditya. 2008. A Cold Look at Education. Dhaka, Bangladesh: New Age, January 30. Accessed 17 February 2008. University Grants Commission. 2011. Poitrishtomo Barshik Protibedon 2010 [37 ${ }^{\text {th }}$ Annual Report 2008]. Dhaka: UGC

Unterhalter, Elaine, Jake Ross, and Mahmudul Alam. 2003. A fragile dialogue? Research and primary education policy formation in Bangladesh, 1971-2001. Compare: A Journal of Comparative and International Education 33(1): 87-98. doi:10.1080/03057920302604

doi:10.1186/s13616-014-0021-2

Cite this article as: Chowdhury and Kabir: Language wars: English education policy and practice in Bangladesh.

Multilingual Education 2014 4:21.

\section{Submit your manuscript to a SpringerOpen ${ }^{\circ}$ journal and benefit from:}

- Convenient online submission

- Rigorous peer review

- Immediate publication on acceptance

- Open access: articles freely available online

- High visibility within the field

- Retaining the copyright to your article

Submit your next manuscript at $\boldsymbol{~ s p r i n g e r o p e n . c o m ~}$ 